\title{
Density and abundance of the red-capped mangabey (cercocebus torquatus) in omo biosphere reserve and idanre forest reserve, south western Nigeria
}

\begin{abstract}
Red-capped mangabey (Cercocebus torquatus) is a partly terrestrial monkey that has experienced $>50 \%$ declines in the population size and the area of occupancy in the last three decades. We conducted primate surveys in Omo Biosphere Reserve and Idanre Forest Reserve to examine the density and abundance of $C$. torquatus between 2012 and 2014 using DISTANCE statistical package. To examine if encounter rates differ by season, we tested the data with Kruskal-Wallis tests. At Omo, we had 21 sightings of $C$. torquatus groups and 17 groups at Idanre. The encounter rates were $0.07 \mathrm{groups} / \mathrm{km}$ at $\mathrm{Omo}$ and 0.05 groups $/ \mathrm{km}$ at Idanre. Sighting was more frequent in the dry season (Kruskal-Wallis test $=3.857 ; \mathrm{p}<0.05)$ than in wet seasons in both forests. The estimated group size was $4 \pm 0.3$ members per group $3 \pm 0.2$ members per group in Omo and in Idanre, respectively.
\end{abstract}

Keywords: terrestrial, occupancy, primates, sightings, kruskal-wallis
Volume 5 Issue 2 - 2017

\author{
Orimaye JO,' Ogunjemite BG, ${ }^{2}$ Agbelusi EA ${ }^{2}$ \\ 'Department of Forest Resources and Wildlife, Ekiti State \\ University, Nigeria \\ ${ }^{2}$ Ecotourism and Wildlife, the Federal University of Technology, \\ Nigeria
}

\begin{abstract}
Correspondence: Orimaye JO, Department of Forest Resources and Wildlife, Ekiti State University, Nigeria
\end{abstract} Email Jacob.orimaye@eksu.edu.ng

Received: January 30, 2017 | Published: March 09, 2017

\section{Introduction}

The red-capped mangabey (Cercocebus torquatus) is a partiallyterrestrial monkey that occurs from the coastal forests from western Nigeria into southern Cameroon, and within the course of Equatorial Guinea (Rio Muni), and Gabon and the Gabon- Congo border on the Atlantic shore. Its southern restriction is south of the Ogooue River in Gabon. There had been unconfirmed opinions of its occurrence in Benin, and if it ever did arise it'll now be extirpated. This species is mainly discovered in excessive wooded area, however it additionally occurs in mangrove, gallery and swamp wooded vicinity. It can also be observed in young secondary forests and close to cultivated regions. Group size has been pronounced to be between 14 and 23 animals in Equatorial Guinea. This species is indexed on Appendix II of CITES and on classification B of the African convention on the Conservation of Nature and Natural Resources. This species is found in some of protected forests in Nigeria, which include: Cross River National Park; Okomu National Park, Douala-Edea Reserve, Banyang-Mbo Wildlife Sanctuary, Dja Reserve Campo- Ma'an National Park, and Korup National Park in Cameroon; Sette Cama Forest Reserve and Mayumba, Loango, Moukalaba-Doudou, and Pongara National Parks (Gabon); Conkouati-Douli National Park in Congo; and Monte Allen National Park in Equatorial Guinea. ${ }^{1}$ The 2008 IUCN Red List categorized this species as vulnerable. ${ }^{2} C$. torquatus is a large mangabey which was once a common monkey in lowland forests of southwestern Nigeria. ${ }^{3,4}$ However, recent study of primates in southwestern Nigeria ${ }^{5}$ had disclosed that the animal population had reduced as evident by its little group sizes in several locations across the region. Although Red-capped mangabey got its name from Madagascar, they live solely on the continent of Africa, for instance, their range is fairly restricted, occupying the West and Central Africa to the Congo Basin in Central Africa Republic. Most of their habitats are being destroyed for agricultural purposes and settlements. ${ }^{6}$

This lowland rain forest monkey occurs in seasonally flooded swamp forests to different types of rain forest. ${ }^{7}$ They are active in the dense vegetation of swamps and gallery forests of primary and secondary forest. ${ }^{8}$ C. torquatus is susceptible to hunting due to its loud vocalizations and its large body size (avg. body wgt. adult male=7$12.5 \mathrm{~kg}$, adult female $=5-8 \mathrm{~kg})^{9}$ that makes them an easy target for hunters and more valuable as bush meat than smaller-bodied guenons. The Southwest eco-zone, west of Niger and between Dahomey-gap are of special ecological consideration. ${ }^{1}$ Most of the endemic and rare species of the region are on the verge of extinction. The red-capped mangabey, being one of the most prominent species of the region is now listed as vulnerable by the IUCN..$^{10}$ Surveys conducted by CERCOPAN in 2007, indicated that C. torquatus is already locally extinct in some isolated patches of swamp forest within the Niger delta, and intensely rare in another space. ${ }^{3,4,9}$ C. torquatus appears to be confined in the restricted forest patches within the Southwestern Nigeria region..$^{1,11}$ This paper is aimed at finding out determining the density and abundance of $C$. torquatus in Idanre Forest Reserve and Omo Biosphere Reserve, Southwestern Nigeria.

\section{Methods}

\section{Study areas and primate species}

This study was carried out in Idanre Forest Reserve (6 ${ }^{\circ} 51^{\prime} 27.72^{\prime}$ ' $\mathrm{N}, 5^{\circ} 6^{\prime} 19.84$ " E, $\left.527.1 \mathrm{~km}^{2}\right)$ in Idanre Forest Cluster and Omo Biosphere Reserve (60 35' to 70 05' N, $4019^{\prime}$ to $4040^{\prime} \mathrm{E}$, in Omo Forest Cluster (Figure 1), Southwest Nigeria. ${ }^{12}$

The primate species that are known to occur at Idanre Forest are white throated monkey (Cercopithecuserythogasterpococki), the Nigerian putty nosed monkey (Cercopithecus nictitans nilotus), Mona monkey (Cercopithecus mona), red-capped mangabey (Cercocebus torquatus) and Chimpanzee (Pan troglodytes) species. ${ }^{12}$ In Omo Forest, there are potto (Perodicticuspotto), demidoffs galago (Galagoides demidovii), mona monkey (Cercopithecus mona), and red-capped mangabey (Cercocebus torquatus) species. ${ }^{13}$

Idanre Forest reserve is characterized by a dry season of about 3-4 months usually between November and February with mean 
annual rainfall of $1,654 \mathrm{~mm} .{ }^{12}$ Wettest periods are usually between July and September, characterized by double maximal rainfall. ${ }^{14}$ The predominant habitat type of Idanre Forest reserve is the Guinea-Congo lowland rain forest. ${ }^{1}$ Some relatively dominant plant species found in the area where natural forest vegetation still exists include Cola spp., Mansonia altissima, Nesogordonia papaverifera, Pterygota spp., Sterculia spp., Triplochiton scleroxylon, Antiaris africana, Ficus spp., Milicia excelsa, Brachystegia spp., Cylicodiscus gabunensis, Gossweilerodendron balsamiferum, Piptadeniastrum africanum. ${ }^{15}$ At OBR, the mean annual rainfall ranges from about 1600 to $2000 \mathrm{~mm}$ with two annual peaks in June and September, with November and February being the driest months. ${ }^{16}$ The Biosphere reserve is home to tropical humid forests, including dry evergreen mixed deciduous forests in the north and wet evergreen forests in the south. However, plantations (Gmelina arborea, Pinus caribaea, Cola $s p$. and Theobroma cacao species), residential areas and agricultural land containing agroecosystems with cash and arable crops are also present. The main plant species in the Omo are Diospyros spp., Dracaena manni, Khaya ivorensis and Cordia millenii. Around 80 percent of the area is well-drained into the watershed of Omo River and metamorphic rocks of the Pre-Cambrian Basement Complex can be found underneath the area. ${ }^{17}$

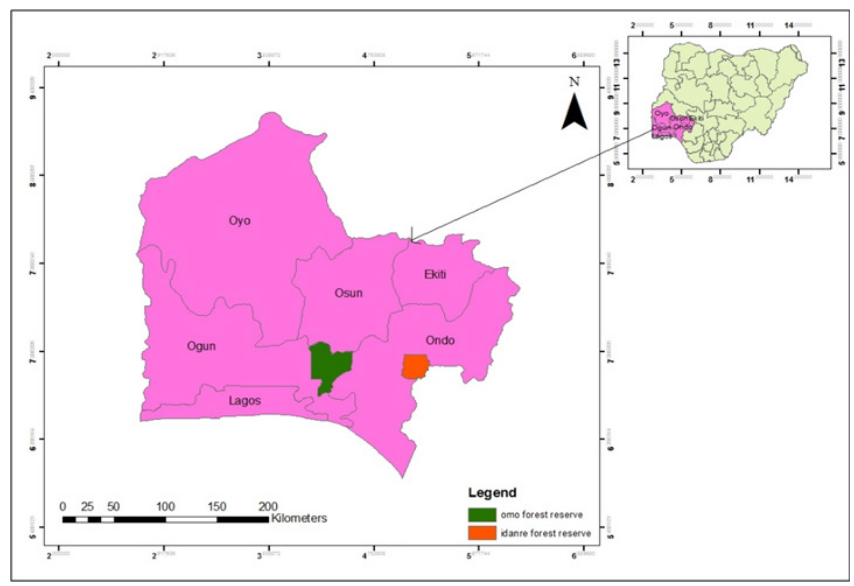

Figure I Southwestern Nigeria showing Omo Biosphere reserve and Idanre Forest reserve.

\section{Source: Field survey.}

\section{Data collection}

We walked a total of nine nature's trails, hunters' trails, or loggers' trails in IFR and nine in OBR between January 2012 and November 2014. The trails ranged in length between $1.9 \mathrm{~km}$ and $3.7 \mathrm{~km}$ with a mean length of $2.8 \mathrm{~km}$ in Omo Forest and between $2.2 \mathrm{~km}$ and $4.0 \mathrm{~km}$ in length with the average length of $3 \mathrm{~km}$ in IFR,. At each study site, the trails were walked in the morning between 6.30 hour and 10.30 hours and in the evening between 16.00 hours to 19.00 hours. The trails were walked slowly at a speed of $1.0-1.5 \mathrm{~km} / \mathrm{hr}$, with regular stops every 50 meters for one minute, to carefully screen all forest strata and detect any movement or sound/noise. The following are the elements recorded during each walk: the perpendicular distance to the transect of the first individual seen, activities of all animals seen, GPS coordinates of the location, time, and the length of transect walked.

\section{Data Analysis}

Survey data obtained from the survey of the red-capped mangabey from the two study areas were processed using DISTANCE statistical package, version 6.0. Kruskal-Wallis and Kolmogorov-Smirnov tests were used to test the significance of the mean of data between the study sites and descriptive statistics such as frequency tables and percentages were used to describe results.

\section{Results}

\section{Transects covered, sightings and mean sighting distances of $C$. torquatus in the study areas}

The result of our transects survey is shown in Table 1. We sighted 9 mangabey groups on nine trails in Omo Forest and 9 groups on transects walked in both OBR and IFR in dry and wet seasons between January 2012 and November 2014 covering a total distance of $626.4 \mathrm{~km}$. At Omo Biosphere reserve, we recorded 21 sightings from 9 transects totaling $303.6 \mathrm{~km}$ translating to one sighting per $3.84 \mathrm{~km}$. In addition, 17 groups of the red-capped mangabey were observed from nine (9) transects covering a distance of $322.8 \mathrm{~km}$ (One animal was sighted in an average distance of $5.98 \mathrm{~km}$ ) in Idanre Forest reserve.

Table I Transects covered, Number of sightings, Mean troop size and Average kilometer per sighting of $C$. torquatus in Omo Biosphere reserve and Idanre Forest reserve

\begin{tabular}{llll}
\hline Measured indices & $\begin{array}{l}\text { Omo } \\
\text { biosphere R }\end{array}$ & $\begin{array}{l}\text { Idanre } \\
\text { forest R }\end{array}$ & Total \\
\hline $\begin{array}{l}\text { Total Number Of } \\
\text { Transect Covered }\end{array}$ & 9 & 9 & 18 \\
$\begin{array}{l}\text { Total Length transect } \\
\text { Covered }(\mathrm{Km})\end{array}$ & 303.6 & 322.8 & 626.4 \\
$\begin{array}{l}\text { Total Number of } \\
\text { Animal Sighted }\end{array}$ & $\left.2\right|^{*}\left(79^{* *}\right)$ & $17^{*}\left(54^{* *}\right)$ & $38^{*}\left(133^{* *}\right)$ \\
$\begin{array}{l}\text { Mean Sighting/ } \\
\text { Kilometer }\end{array}$ & $\begin{array}{l}\text { I.Sighting/ } \\
3.84 \mathrm{~km}\end{array}$ & $\begin{array}{l}\text { I Sighting / } \\
5.98 \mathrm{~km}\end{array}$ & \\
\hline
\end{tabular}

*Troop numbers, **Individual animals sighted

\section{Sightings of $C$. torquatus in the study areas}

Our general sighting trend of C. torquatus is shown in Figure 2 below. We observed 1 group ( $\mathrm{n}=4$ individuals) and 4 groups $(\mathrm{n}=18$ individuals) of C. torquatus during the wet and dry seasons in 2012, 3 groups ( $\mathrm{n}=9$ individuals), 4 groups ( $\mathrm{n}=17$ individuals) in both seasons in 2013 and 2 groups ( $\mathrm{n}=9$ individuals), 6 groups ( $\mathrm{n}=22$ individuals) in both seasons in 2014. This translates to $28.6 \%, 33.3 \%$ and $38.1 \%$ of the overall sightings in 2012, 2013 and 2014 respectively in OBR. The sightings of $C$. torquatus was more frequent in dry seasons than in wet seasons and was statistically significant $(p<0.05)$, (KruskalWallis test $=3.857 ; p=0.04953)$ in addition, we observed 1 group $(\mathrm{n}=3$ individuals) and 6 groups ( $\mathrm{n}=16$ individuals) in wet and dry seasons of 2012, 1 group ( $\mathrm{n}=2$ individuals) and 5 groups ( $\mathrm{n}=17$ individuals) in both seasons in 2013, 1 group ( $\mathrm{n}=2$ individuals) and 3 groups $(\mathrm{n}=14$ individuals) in both seasons in 2014 respectively. This translates to $27.85 \%, 32.91 \%$ and $39.24 \%$ of the overall sightings between 2012 and 2014 respectively in IFR. Sighting of $C$. torquatus groups was more in dry seasons than in wet seasons throughout the year 2012 to 2014 and were statistically significant $(p<0.05)$, (Kruskal-Wallis test $=3.971 ; p=0.0463$ ).

\section{Encounter rate; troop size; density and abundance of C. torquatus in the study area}

Table 2 shows the encounter rate and troop size, density and abundance of $\mathrm{C}$. torquatus in the study area. At OBR, we estimated the overall encounter rate of $C$. torquatus to be 0.07 animal $/$ kilometer, 
the mean group size as $4 \pm 0.266$ individual animals per group while the density was $0.26 \pm 0.08$ animals $/ \mathrm{km}^{2}$ and the abundance estimate of $C$. torquatus showed that the animal has the population estimate of about $454.00 \pm 93$ animals within the biosphere reserve $\left(150 \mathrm{~km}^{2}\right)$. In addition, our result for the encounter rate at IFR yielded $3 \pm 0.23$ animals per group, the mean group size was 0.05 animal $/$ kilometer The density estimate was $0.14 \pm 0.01$ animals $/ \mathrm{km}^{2}$ while abundance estimate of $C$. torquatus in IFR (about $527.1 \mathrm{~km}^{2}$ ) showed that the animal has the population of about $958.00 \pm 110$ animals within the forest reserve.

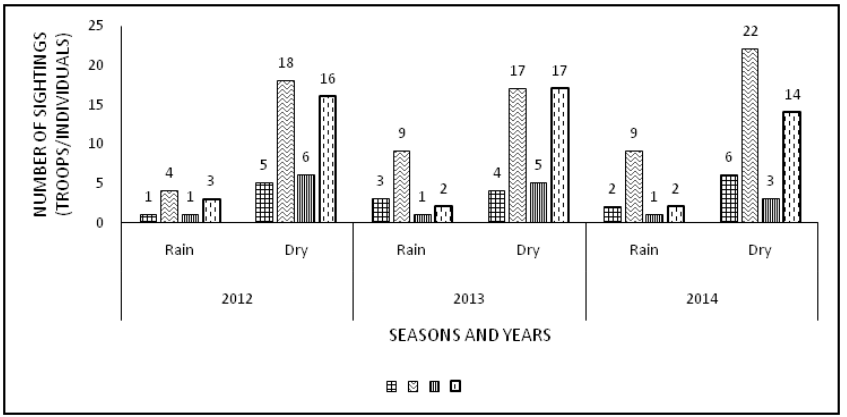

Figure 2 Sightings of $C$. torquatus in the study areas.

Source: Field Survey.

Table 2 Troop size, encounter rate and density of $C$. torquatus in the study area

\begin{tabular}{lll}
\hline Study areas & $\begin{array}{l}\text { Omo biosphere } \\
\text { reserve }\end{array}$ & $\begin{array}{l}\text { Idanre forest } \\
\text { reserve }\end{array}$ \\
\hline Mean troop Size & $4 \pm 0.266$ & $3 \pm 0.23 \mathrm{I}$ \\
Encounter rate (Animal $/ \mathrm{km})$ & 0.07 & 0.05 \\
Density (Animal $\left./ \mathrm{km}^{2}\right)$ & $0.26 \pm 0.08$ & $0.14 \pm 0.01$ \\
Abundance & $454.00 \pm 93$ & $958.00 \pm 110$ \\
\hline
\end{tabular}

\pm : Standard error

Source: Field survey

\section{Discussion}

We sighted $C$. torquatus at both OBR and IFR. The results of the sightings indicated that the number of individuals and groups of $C$. torquatus we sighted during the dry season exceeded the number sighted in the wet season at both study sites. This observation agreed with the results of ${ }^{18}$ and that the excessive rain during the wet season, which obviously boosts up regeneration and growth of herbaceous and ground vegetation, might have provided thick cover for the animals, which makes their sighting difficult. Furthermore, few numbers of fruiting trees during the dry season constrained the animal to travel far in search of food accounted for more sighting in the dry season than the wet season. The results also showed that the estimated group size was higher in Omo Biosphere reserve compared to Idanre Forest reserve. Notwithstanding, these group sizes were lower than the previous reports of between 5 to 8 animals in Okomu National Park. ${ }^{19,20}$ Furthermore, it also falls short of the group size of forest primate species of related ecology within the Nigerian rain forest ecosystem. The possible explanation for this might be the low level of protection and the unabated incidence of illegal hunting which had been on the increase in the study areas. ${ }^{21}$

Although there have been efforts to stop illegal hunting in Omo Biosphere reserve with little results, the mono-cultural cultivation of exotic tree species to replace the natural forests has yielded negative results. These exotic tree species lowers the habitat quality of $C$. torquatu $s$ thereby reducing food available to the animal. Emery Thompson et al., ${ }^{21}$ submitted that reduction in the quality of primates' habitat and logging pressure may affect the reproductive success of female primate. Therefore, a reduction in food availability associated with logging and planting of exotic tree species decreases the animals' condition and increase their vulnerability to disease or parasites ${ }^{22}$ and also increase juvenile mortality. In addition, $C$. torquatus spends most of its time on the canopy of the middle strata of the forest and is highly sensitive to timber logging. Continuous and unabated logging in the study sites could have been the reason for the small group size because the protection offered by close canopy forest is absent. By instinct, the animal breaks into smaller group sizes to reduce the chances of being spotted by hunters during hunting adventure. This hypothesis was in agreement with the findings of Rovero and Struhsaker, ${ }^{23}$ where they reported that Red Colobus monkey (Procolobus rufomitratus) groups are negatively affected by forest degradation.

We recorded higher encounter rate of $C$. torquatus in OBR than in IFR. Yet, these observations were lower than the resent findings of Akinsorotan et al., ${ }^{24}$ with $0.10 \mathrm{group} / \mathrm{km}$ in Okomu National Park. Earlier, Strushaker ${ }^{8}$ had reported this species as 'common' in both Douala-Edea R and Korup National Parks, which were part of the range of the animal. Since then, the encounter rate has gradually declined to 0.23 groups $/ \mathrm{Km}^{2}$ in $1999 ; 0.14 \mathrm{groups} / \mathrm{km}^{2}$ in $2000 ; 25$ 0.01 groups $/ \mathrm{km}^{2}$ in 2004 and $2005 ;{ }^{26} 0.02$ groups $/ \mathrm{km}^{2}$ in 2006,2007 and 2008. ${ }^{27}$ This reducing encounter rate may have been due to hunting and habitat alteration, worsened by the negative consequences of a programme of agricultural development assistance to migrant farmers. In addition, ${ }^{19,28,29}$ and Ogunjemite et al., ${ }^{30}$ reported that the rate of exploitation of Southwestern Nigerian forest ecosystems was over five times higher than the rate of forest regeneration, and logging pressure was intense and on the increase. It is, therefore, clear that many wildlife species including $C$ torquatus have been threatened by widespread habitat loss for a very long time.

Surveys (since 1995) in Southwestern Nigeria had indicated that $C$ torquatus is locally extinct or rare in a number of areas of the Niger-Delta and Akwa Ibom ${ }^{31}$ We observed low population density of animals per square kilometer in the study area. This could mean that the entire primate community in this forest is under threat from habitat destruction and hunting. ${ }^{32}$ These observations supported Kingdon ${ }^{31}$ submission that the $C$ torquatus which was once a widespread, successful species, is declining rapidly from all areas where habitat loss to agricultural expansion and intensive hunting occur. The importance of protection level from hunting and disturbance is further underscored by the abundance estimates for both OBR $(150 \mathrm{~km} 2)$ and IFR $\left(527.1 \mathrm{~km}^{2}\right)$.

\section{Conclusion}

$C$ torquatus had been presumed to be abundant in the region of southwestern Nigeria and this should have been reflected on its population in these protected areas that are believed to be supporting the remaining population of the biological diversity of Southwestern Nigeria. However, we observed a very low density of $C$. torquatus in the study areas which cast doubt about the general well-being of the population of this animal in the region. There is clear evidence that this animal is reducing in number on daily basis due to habitat degradation and hunting pressure. ${ }^{33-42}$ The group size, encounter rate, density per unit area and abundance of the animal in the study areas fall short of what was reported earlier. The habitat of the animal is being destroyed through our land use policies, planting of exotic plant 
species to replace the natural forest which provides the animal with food. All these are taking their toll on the wellbeing of the animal. It is, therefore, clear that the status of $C$ torquatus which was considered as vulnerable by IUCN classification some years back may have been threatened or even endangered by the alarming widespread of habitat modification if unchecked.

\section{Recommendation}

The present management structures for protected areas were planned under different conditions and are not necessarily able to adapt to these new pressures going on within the protected areas. We recommend that communities in and around the protected areas should be encouraged to establish 'Village Conservation Associations' (VCA) among the human settlements which should be used to promote local participation in sustainable conservation practices and improve the cooperation with local communities in conservation planning and management through community-based management options.

\section{Acknowledgements}

None.

\section{Conflict of interest}

The author declares no conflict of interest.

\section{References}

1. Oates JL, Ikemeh RA, Bergl RA. A survey of rainforests in Ogun, Ondo and Osun States in Southwestern Nigeria to assess options for sustainable conservation. Nigeria: NCF; 2008.

2. Oates JL, Adeleke A. Chimpanzees in Nigeria and their habitats. In: Kormos R, et al. editors. Status Survey and Conservation Action Plan: West African Chimpanzees. Switzerland: Gland; 2003.

3. Agbelusi EA, Ogunjemite BG, Afolayan T. A survey of the primates of Ondo and Ekiti State. Journal of Tropical Ethnoforestry. 1999;2(1):100106.

4. Person HM, Warner MD. The chimpanzees and other primates of Omo Forest Reserve. The Nigerian Field. 2003;68:160-167.

5. Amakulo UM, Akinpelu AI. A study of the diurnal primates in Shasha Forest Reserve, Ife South Local Government Area, Osun State Nigeria. In: Ofoezie O, Awoteye O, Adewole MB, editors. Many species one Planet, one future. Proceedings of the 3rd Annual conference of the Institute of Ecology and Environmental studies; 2010. p. 45- 54.

6. Greengrass EJ. A Survey of Chimpanzee in South West Nigeria. 2006.

7. Jones C, Sabater Pi C. Comparative Ecology of Cercocebus albigena (Gray) and Cercocebus torquatus (Kerr) in Rio Muni West Africa. Folia Primatol. 1968;9(2):9-11.

8. Gartlan JS, Struhsaker TT. Polyspecific association and niche Separation of rainforest anthropoids in Cameroun, West Africa. J Zool Soc London. 1972;168(2):221-265.

9. http://www.http://cercopan.org/home.html

10. www.IUCNredlist.org

11. Ogunjemite BG. Trends in the Chimpanzees of Kukuruku Hills: Indication of Extinction in the Population of Chimpanzees of South-west Nigeria. Nigerian Journal of Forestry. 2006;36(2):116-125.

12. Ikemeh RA. Sustainable forest management in a human dominated landscape and its implications for biodiversity conservation: a Nigerian lowland forest perspective. Dove press; 2013. 2013:9-23.

13. Ola-Adams BA. Biodiversity Inventory of Omo Biosphere Reserve. Nigeria: Nigeria national mab committee; 2014. p. 1-65.
14. Greengrass EJ, Ogunjemite BG. The effects of severe fragmentation and hunting on chimpanzee populations in Nigeria. The Primate Eye, 2008. $182 \mathrm{p}$

15. Werre JR. Nigerian Lowland Ecoregion. 2001.

16. Isichei AO. Omo Biosphere Reserve, Current Status, Utilization of Biological Resources and Sustainable Management (Nigeria). France: Working Papers of the South-South Cooperation Programme on Environmentally Sound Socio-17. Economic Development in theHumid Tropics, UNESCO; 1995.

17. http://www.unesco.org/new/en/natural-sciences/environmet/ecologicalscience/man-an-biosphere-programme/networks/afrimab/gebr-roject/ omo-biosphere-resrve/

18. Ajibade W, Agbelusi AA. Population density and distribution of green monkey (Cercopithecus aethiops. linnus 1758) at Zugurma sector of Kainji lake national park, Nigeria. Afr J Agric Res. 2011;6:2456-2460.

19. Anadu PA, OatesJF. The Status of Wildlife in Bendel State, Nigeria, with Recommendations for its Conservation. Nigeria: the New York Zoological Society, New York, and the World Wildlife Fund: Report to the Bendel State Ministry of Agriculture and Natural Resources, Benin, the Nigerian Federal Ministry of Agriculture, Abuja, the Nigerian Conservation Foundation; 1982.

20. Koyenikan IO. Impact of human activities on the primates of Okomu National Park, Edo State, Nigeria. Nigeria: Federal University of Technology, Master of Agricultural Technology Thesis; 2004.

21. Emery Thompson MS, Wrangham RW. Core area quality is associated with variance in reproductive success among female chimpanzees at Kibale National Park. Animal Behaviour. 2007;73(3):501-512.

22. Chapman CA, Balcomb SR, Gillespie TR, et al. Long-term effects of logging on African primate communities: a 28-year comparison from Kibale National Park, Uganda. Conservation Biology. 2000;14(1):207217.

23. Rovero F, Struhsaker TT. Vegetative predictors of primate abundance: utility and limitations of a fine-scale analysis. Am $J$ Primatol. 2007;69(11):1242-1256.

24. Akinsorotan OA, Ogunjemite BG, Afolayan TA. Assessment of Large Mammals of Arakhuan Range, Okomu National Park. Ethiopian Journal of Environmental Studies and Management. 2011;4(3):2011.

25. Waltert M, Lien K, Muhlenberg M. Further declines of threatened primates in the Korup Project Area, south-west Cameroon. Oryx. 2002;36(3):257-265

26. Linder JM. The impact of hunting on primates in Korup National Park, Cameroon: implications for primate conservation. USA: The City University of New York; 2008.

27. Astaras C, Krause S, Mattner L, et al. Associations between the drill (Mandrillus leucophaeus) and sympatric monkeys in Korup National Park, Cameroon. Am J Primatol. 2011;73(2):127-134.

28. Agbelusi EA. Wildlife conservation in Ondo State. Nigerian Field 1994;59:73-83.

29. Anadu PA. Wildlife conservation in Nigeria: problems and strategies. The Environmentalist. 1987;7(3):211-220.

30. Ogunjemite BG, Afolayan TA, Agbelusi EA. Habitat Structure of Chimpanzee Community in Ise Forest Reserve, Ekiti State, Southwestern Nigeria. African Journal Ecology. 2005;43(4):396-399.

31. Kingdon J. The Kingdon Field Guide to African Mammals. USA: Academic Press; 1997.

32. Araldi AB. Density estimation of the endangered Udzungwa red colobus (Procolobus gordonorum) and other arboreal primates in the Udzungwa Mountains using systematic distance sampling. International Journal of Primatology. 2014;35(5):941-956. 
33. Afolayan TA, Agbelusi EA, Ogunjemite BG. Resources Conservation and Your Future. In: Egunjobi, et al. editors. Environmental degradation, reclamation, conservation and pollution control. Nigeria: The Nigerian National Commission for UNESCO; 2004.

34. http://www.africanwildlifevacations.com/

35. Agbelusi EA, Ogunjemite BG, Koyenikan IO. The primate fauna and the distribution of chimpanzees of Okomu National Park, Edo State, Nigeria. Journal Tropical Forest Resource Management. 2003;19:161-170.

36. Akinyemi AF, Odutan OO. An evaluation of the effect of conservation legislation on wildlife offences in the Yankari National Park, Bauchi, Bauchi State. Nigerian Journal of Forestry. 2004;34(1):28-35.

37. Chapman CA, Lawes MJ, Eeley HA. What hope for African primate diversity? African Journal of Ecology. 2006;44(2):116-133.
38. www.worldclim.org

39. Zerihun G, Yosef M, Mateos E. Species Composition, Distribution and Relative Abundance of Large Mammals in and around Wondo Genet Forest Patch, Southern Ethiopia. Asian Journal of Applied Sciences. 2012;5(8):538-551.

40. www.IUCNredlist.org

41. Ogunjemite BG, Agbelusi EA, Afolayan TA, et al. Status survey of Chimpanzee in the forest zone of Southwestern Nigera. Act Zool Sinica. 2006;52(6):1009-1014.

42. Ojo LO. The fate of a tropical rainforest in Nigeria: Abeku sector of Omo Forest Reserve. Global Nest. 2004;6(2):116-130. 